\title{
Evaluation of Herbal Choline and Methionine Supplementation on a Milk Production in Dairy Cows
}

\section{Fulencio Ferretiz-Rodríguez ${ }^{1}$, Jose Alejandro Roque-Jiménez ${ }^{1}$, Héctor A. Lee-Rangel ${ }^{1 *}$, Gregorio Alvarez-Fuentes ${ }^{1}$, Juan Carlos Garcia-LopeZ ${ }^{1}$, Rolando Rojo-Rubio ${ }^{2}$}

\author{
${ }^{1}$ Facultad de Agronomiay Veterinaria, Centro de Biociencias, Instituto de Investigaciones en Zonas Deserticas, \\ Universidad Autónoma de San Luis Potosi, SLP, México; ${ }^{2}$ Centro Universitario UAEM-Temascaltepec, Universidad \\ Autónoma del Estado de México.
}

\begin{abstract}
Polyherbal additives represent an alternative to enhance the productivity in dairy cattle. Some herbal mixtures with conjugates of choline and methionine have improved milk yield in dairy cattle. An experiment was conducted to evaluate two herbal formulas as sources of choline and methionine on dairy cows production and metabolites change. Thirty-two Holstein cows (Body Condition Score $3.01 \pm 0.16)$ fed a basal diet, were randomly assigned to one of four treatments: Control diet, Biocholine (BIO) supplementation (15 grams/cow/day), Optimethionine (OP) supplementation ( 9 grams/cow/day), and $\mathrm{BIO}$ x OP supplementation, with a duration of 60 days. Optimethionine treatments decrease milk production $(\mathrm{P} \leq 0.05)$, but fat corrected production was higher $(\mathrm{P} \leq 0.05)$ when cows were supplemented with BIO. The chemical composition of the milk did not show differences between treatments. Plasma urea and cholesterol were not different between treatments, glucose shown a decrease $(\mathrm{P} \leq 0.05)$ whit supplementation. Aspartate transferase activity decrease $(\mathrm{P} \leq 0.05)$ with $\mathrm{BIO}$ supplementation. Results indicate that the herbal $\mathrm{BIO}$ and $\mathrm{OP}$ present some productive and metabolic changes.
\end{abstract}

Keywords | Dairy cows, Choline, Methionine, Herbal formulas, Phytogenic sources

Received | October 19, 2021; Accepted | December 24, 2021; Published | January 15, 2022

*Correspondence | Héctor Aarón Lee-Rangel, Facultad de Agronomíay Veterinaria, Centro de Biociencias, Instituto de Investigaciones en Zonas Deserticas, Universidad Autónoma de San Luis Potosí, SLP, México, SLP, México, CP 78000; Email: hector.lee@uaslp.mx

Citation | Ferretiz-Rodríguez F, Roque-Jiménez JA, Lee-Rangel HA, Alvarez-Fuentes G, Garcia-Lopez JC, Rojo-Rubio R (2022). Evaluation of herbal choline and methionine supplementation on a milk production in dairy cows. Adv. Anim. Vet. Sci. 10(3): 544-547.

DOI | http://dx.doi.org/10.17582/journal.aavs/2022/10.3.544.547

ISSN (Online) | 2307-8316

\section{INTRODUCTION}

$\mathrm{F}$ eed plant additives and their secondary metabolites used as additives could be oriented to modify rumen fermentation to increase nutrient utilization mainly in adult ruminant productions, in anthelmintic effects, and as immunity stimulants as well as in other physiological effects (Sanchez et al., 2021). Feed plant additives may represent an alternative means to improve health and production in dairy cattle. Still, it is necessary to identify effective products, adequate dosage, and optimal conditions to obtain the benefits (Ortega-Alvarez et al., 2020). Some polyherbal mixtures with choline and herbal methionine conjugates have improved milk yield in dairy cattle (Mendoza et al., 2020).

The conventional supplementation of ruminal-protected nutrients (amino acids or choline) has demonstrated that they can improve milk yield (Martínez-García et al., 2021). However, increasing milk yield may also increase metabolic problems and other production diseases and reduce fertility (Ortega-Alvarez et al., 2020). Mendoza et al. (2020) mentioned that the use of biocholine and optimethionine in dairy cows can improve milk production due to the phytochemical content of these additives. In the period of transition to lactation, the cows present a negative energy and protein balance due to increased metabolic demand from the mammary gland (Lara et al., 2006). Since methyl donors must synthesize critical compounds such as phosphatidylcholine and carnitine in tissues, a negative methyl donor balance may also be a fundamental challenge for the transition dairy cow (Mendoza et al., 2020). Thus, the possibility to increase the duodenal flow should be evaluated for improving milk production in dairy cows by choline and methionine. Therefore, the aim of this experiment was to determine the effect of $\mathrm{BIO}$ and $\mathrm{OP}$ on 
dairy cows' body score condition (BSC), milk production and composition, and changes on urea, cholesterol, and AST plasmatic.

The animal procedures were reviewed and approved by the Committee for the Ethical Use of Animals in Experiments of the Universidad Autonoma de San Luis Potosi (UASLP), according to the regulations and standards that are required by the Mexican government for the use of animals for a number of diverse activities (NOM-062ZOO-1995). The animals were vaccinated with Bobact $8^{\circledR}$ and dewormed twice a year. The Dairy Farm have different biosecurity practices such sanitation, feed management, facility maintenance, manure handling, and disposal of dead animals. All cows were allowed in pens to high fresh and the high producers; the specific pen was designed in pie-shape are equipment with automatic watering system, the cows were milking twice a day (at 5:00h am and 15:00h pm) in a pipeline automatic machine programmed for recorder the individual production by approximately ten minutes. The milking parlor was disinfected daily, and the milking machine was cleaned every day. A professional pest control company gives the service to extermination, fumigation, and rodents prevention.

The experiment was conducted at the experimental farm of the UASLP $\left(22^{\circ} 11^{\prime} \mathrm{N}, 100^{\circ} 56^{\prime} \mathrm{O}, 1850 \mathrm{~m}\right.$ above sea level) with a mean temperature of $17.5^{\circ} \mathrm{C}$. The experimental period has a duration of 60 days, where 32 Holstein cows (eight cows for treatment; BSC $3.01 \pm 0.16$ ) with five days after parturition were assigned randomly to one of four treatments: (1) Control diet; (2) Biocholine (BIO) supplementation (15 grams/cow/day; Nuproxa México); (3) Optimethionine (OP) supplementation (9 grams/cow/ day; Nuproxa Mexico); and (4) BIO x OP supplementation. The basal diet contains $(16.3 \% \mathrm{CP}$ with $6 \%$ of DRP, and $2.08 \mathrm{Mcal} / \mathrm{kg} \mathrm{ME}$ ) oat hay, alfalfa hay, rolled corn, and concentrate (65\% forage, $35 \%$ concentrate). The treatments were given individually in the milking parlor at 06:00 hours.

Milk production was recorded daily, and its composition (fat, protein, lactose, total solids, and non-fatty solids) was characterized every seven days using the samples taken during the early and afternoon milking. Previous to analysis the samples were mixed and homogenized in a water bath during one minute until the samples reaches $29^{\circ} \mathrm{C}$. Later the samples were analyzed using the Lactoscan Ultrasonic milk analyzer (Milkotronic ${ }^{\circledR}$, Bulgaria). The 4\% fat corrected milk (FCM) of each cow was calculated as follows: $\mathrm{FCM}=[(0.4 \mathrm{~kg}$ milk $)+(0.15 \mathrm{~kg}$ milk fat $\%)]$ by the formula proposed by DeFrain et al. (2006). The BSC was assessed twice on days 1 and 56 using the scale of 1 to 5 , in increments of 0.25 according to Edmonson et al.
(1998), at the time of enrollment. At final of the trial a 32 blood samples were taken, after were centrifuged to obtain blood serum to analyze cholesterol, glucose, and aspartate aminotransferase (AST) using a Biochemistry Analyzer $\left(\right.$ Kontrolab $\left.^{\circledR}\right)$ Shapiro-Wilk tests was used to test normal distribution and data were analyzed as a completely randomized design with the $\mathrm{R}$ software testing for interaction of $\mathrm{BIO} \times \mathrm{OP}$. The lactation days was tested as a covariate. The model for this design is $Y_{i j}=\mu+\varepsilon_{i j}$, were $Y_{\mathrm{ij}}=$ response variable; $\mu=$ mean effect of treatment and; $\varepsilon_{\mathrm{ij}}=$ error.

Milk production showed significant changes $(\mathrm{P} \leq 0.05$, Table 1) between treatments, where the OP supplementation treatment is lower than the others. Some authors reported that 12 to 15 grams per day of RPC increase milk production by about 7 to $8 \%$ above unsupplemented groups (Lima et al., 2012), representing approximately two $\mathrm{kg} / \mathrm{d}$ of milk, like that observed in this experiment. Even when some experiments have used doses of 25 to $60 \mathrm{~g}$ of different choline chloride-based RPC sources (Zhou et al., 2016) or higher doses (Banevičius et al., 2016; Pinotti et al., 2005) concluded that the best responses to improve milk production are obtained when providing $12-20 \mathrm{~g} / \mathrm{day}$ of RPC which is similar to the dose used with the herbal product.

Table 1: Effect of supplementation of BIO and OP on dairy cows performance, chemical milk composition, plasmatic urea, cholesterol, glucose and aspartate transferase concentration during 60 days.

\begin{tabular}{|c|c|c|c|c|c|}
\hline & Control & BIO & OP & BIOxOP & SEM \\
\hline Milk yield, $\mathrm{kg} / \mathrm{d}$ & $30.1^{\mathrm{b}}$ & $29.75^{\mathrm{ab}}$ & $27.01^{\mathrm{a}}$ & $28.6^{\mathrm{ab}}$ & 0.67 \\
\hline 4\% FCM, kg/d & $29.9^{a}$ & $32.24^{\mathrm{b}}$ & $29.19^{a}$ & $26.78^{a}$ & 0.82 \\
\hline \multicolumn{6}{|c|}{ Body score condition } \\
\hline Day 1 & 2.81 & 3.00 & 3.18 & 2.87 & 0.13 \\
\hline Day 56 & 3.10 & 3.00 & 3.18 & 3.00 & 0.08 \\
\hline \multicolumn{6}{|c|}{ Chemical composition, $\mathrm{g} / \mathrm{kg}$} \\
\hline Fat & 3.97 & 4.81 & 4.53 & 3.57 & 0.51 \\
\hline Protein & 2.97 & 2.91 & 3.03 & 3.02 & 0.08 \\
\hline Lactose & 4.51 & 4.39 & 4.6 & 4.57 & 0.32 \\
\hline Total solids & 8.19 & 8.12 & 8.33 & 8.31 & 0.19 \\
\hline \multicolumn{6}{|c|}{ Plasmatic metabolites } \\
\hline Urea & 19.1 & 17.7 & 18.75 & 21.09 & 5.09 \\
\hline Cholesterol & 227.59 & 221.06 & 217.79 & 196.73 & 13.65 \\
\hline Glucose & $103.31^{b}$ & $91.28^{\mathrm{a}}$ & $91.58^{\mathrm{a}}$ & $89.52^{\mathrm{a}}$ & 15.23 \\
\hline $\begin{array}{l}\text { Aspartate } \\
\text { transferase }\end{array}$ & $876.9^{b}$ & $844.69^{a}$ & $875.36^{b}$ & $852.45^{\mathrm{ab}}$ & 18.92 \\
\hline
\end{tabular}

SEM: standard error of the mean. ${ }^{a, b, c}$ Rows with different literal differ $(\mathrm{P}<0.05)$. 
Regarding rumen-protected methionine, Lara et al. (2006) evaluated various doses of rumen-protected methionine (RPM), and milk production increased up to $14 \%$ above the control with 16 grams per day and then decreased. A similar response was observed in first-stage heifers with doses of 14 to $16 \mathrm{~g} / \mathrm{d}$ (Ayala et al., 2010). In both studies, milk protein concentration was increased by RPM. Zhou et al. (2016) observed a 9\% increase in milk production with an estimated dose of $14 \mathrm{~g} / \mathrm{d}$ and higher milk protein content. Mendoza et al. (2020) supplemented dairy cows whit herbal choline and methionine. They found that a combination of these products increases the milk production until 1.07 liters/cow/day, contrary to what was observed in the present experiment.

Fat-corrected milk production increased in the treatment of cows supplemented with $\mathrm{BIO}(\mathrm{P} \leq 0.01)$, which coincides with that reported by Mendoza et al. (2020), who used the same sources in combination and reported a significant increase. Patton et al. (2015) report increases in production corrected for the effect of protected choline or methionine. However, few studies are evaluating herbal compounds. The chemical composition of milk showed no differences between treatments $(\mathrm{P} \leq 0.05$, Table 1$)$ for $\mathrm{OP}$ and $\mathrm{BIO}$ supplementation. Considering that methionine has been identified as one of the two most limiting amino acids for lactating cows (NRC, 2001), reaching the protected methionine requirement improves milk protein synthesis (Zhou et al., 2016) not happen in the present investigation.

No statistically significant differences were observed between treatments for plasma urea levels. Plasmatic urea decrease is associated with a higher pregnancy rate and lower early embryonic losses before pregnancy recognition (Rajala-Schultz, 2001). When the intake of degradable protein is high, or the input of degradable carbohydrates is low, the level of ammonium in the rumen increases and exceeds the amount that bacteria can utilize; when there is excess ammonium, it passes to the liver through the blood, where it is transformed and eliminated, resulting in increased urea levels in the blood (Arias and Nesti, 1999). The NRC (2001) points out that a low ratio between methionine and lysine in the diet may have an impact on the decrease of urea concentration in dairy cattle, the Lis: Met ratio should be $3: 1$, so that the requirements of these two amino acids are covered mainly in diets based on corn silage, such as the diet of this study (Duque-Quintero et al., 2017). The supplementation with $\mathrm{BIO}$ or OP supplementation does not have a significative effect on plasma cholesterol levels in Holstein cows. Phosphatidylcholine is a phospholipid component in mitochondrial membranes; its status affects liver function and lipid levels (Roque-Jimenez et al., 2020); therefore, choline may be suggested to increase hepatic lipid transport in low-fat diets. Hajilou et al. (2014), with a low-fat diet $(2.66 \%$ fat), reported a reduction in triglycerides with supplementation choline in Holstein steers, but cholesterol levels were not affected. The plasmatic concentration of glucose decrease $(\mathrm{P} \leq 0.05)$ by the effect of BIO and OP. The hepatoprotective effects of choline and methionine may directly or indirectly alter glucose metabolism in the liver and prevent metabolic disorders. Choline's lipotropic action may prevent hepatic lipidosis, which is credited for limiting gluconeogenesis (Osorio et al., 2014), and methionine supply may protect the liver from oxidative stress and inflammation that inhibits function; metabolism of both nutrients can biochemically contribute intermediates to the TCA cycle and potentially gluconeogenesis (Chandler and White, 2019)

For aspartate transferase activity (AST), the treatments with $\mathrm{BIO}$ decreased AST $(\mathrm{P} \leq 0.05)$ on treatments that did not receive it. A hepatic protective function has been related to choline consumption. This has been shown from its antioxidant action, lipotropic, in integrity and signaling functions of cell membranes (Fardet, 2010). Its supplementation has reduced some liver enzymes, indicating an improvement in the hepatic status of dairy cattle (Rahmani et al., 2014) and the increase of cholinedeficient diets in piglets (Getty and Dilger, 2015), Sanchez et al. (2021) mentioned that AST levels could be attributable to the herbal formulas containing bioactive substances, with a possible role in decrease diseases by the phytogenic proprieties. Results allow concluding that the herbal choline and methionine can be improved by supplementing cows with the evaluated herbal sources due to changes in plasmatic glucose and AST.

\section{NOVELTY STATEMENT}

The authors propose using polyherbal mixtures that contain choline and methionine. The results suggest that herbal sources of aminoacids influence the productivity of dairy cows and generate some change in plasmatic parameters as AST concentrations.

\section{AUTHOR'S CONTRIBUTION}

Hector A. Lee-Rangel designed the experiment. Fulgencio Ferretiz-Rodriguez, Gregorio Alvarez-Fuentes and Jose Alejandro Roque-Jimenez conducted the experiment and collected samples. Hector A. Lee-Rangel and Juan Carlos Garcia-Lopez analyzed the sample and data. Hector A. Lee-Rangel and Fulgencio Ferretiz-Rodriguez wrote the manuscript. Rolando Rojo-Rubio revised the manuscript.

\section{CONFLICT OF INTEREST}

The authors have declared no conflict of interest. 


\section{REFERENCES}

Arias J, Nesti de Alonso A (1999). Importancia de los niveles de nitrógeno ureico en leche y sangre en el ganado lechero. Rev. Fac. Agron. 16(5): 553.

Ayala J, Mendoza GD, Pinos JM, Lara A, Sánchez MT (2010). Effects of fat and rumen-protected methionine supplementation on production response of first-lactation cows. Acta Agric. Scandinav., 60: 159-165. https://doi.org/1 0.1080/09064702.2010.511254

Banevičius E, Einorytė J, Falkauskas R (2016). Choline chloride possible impact on cow's productivity. Vet. Zootech., 73(95).

Chandler TL, White HM (2019). Glucose metabolism is differentially altered by choline and methionine in bovine neonatal hepatocytes. PLoS One, 14(5): e0217160. https:// doi.org/10.1371/journal.pone.0217160

DeFrain JM, Hippen AR, Kalscheur KF, Schingoethe DJ (2006). Feeding lactose to increase ruminal butyrate and the metabolic status of transition dairy cows. J. Dairy Sci., 89(1): 267-276. https://doi.org/10.3168/jds.S00220302(06)72091-4

Duque-Quintero M, R Rosero-Noguera, Olivera-Ángel M (2017). Digestion de materia seca, proteína cruda y aminoácidos de la dieta de vacas lecheras. Agron. Mesoam., 28(2): 341-356. https://doi.org/10.15517/ma.v28i2.25643

Edmonson AJ, Lean IJ, Weaver DL, Farver T, Webster G (1998). A body condition-scoring chart for Holstein dairy cows. J. Dairy Sci., 72: 68-78. https://doi.org/10.3168/jds.S00220302(89)79081-0

Fardet A (2010). New hypotheses for the health-protective mechanisms of whole-grain cereals: What is beyond fibre? Nutr. Res. Rev., 23(1): 65-134. https://doi.org/10.1017/ S0954422410000041

Getty CM, Dilger RN (2015). Moderate perinatal choline deficiency elicits altered physiology and metabolomic profiles in the piglet. PLoS One, 10(7): 8. https://doi.org/10.1371/ journal.pone. 0133500

Hajilou M, Dehghan-Banadaky M, Zali A, Rezayazdi K (2014). The effects of dietary L-carnitine and rumen-protected choline on growth performance, carcass characteristics and blood and rumen metabolites of holstein young bulls. J. Appl. Anim. Res., 42(1): 89-96. https://doi.org/10.1080/0 9712119.2013.822807

Lara A, Mendoza GD, Landois L, Barcena R, Sánchez-Torres MT, Rojo R, Vega S (2006). Milk production in Holstein cows supplemented with different levels of ruminally protected methionine. Livest. Sci., 105(1-3): 105-108. https://doi.org/10.1016/j.livsci.2006.04.032

Lima FS, Sa Filho MF, Greco LF, Santos JEP (2012). Effects of feeding rumen-protected choline on incidence of diseases and reproduction of dairy cows. Vet. J., 193(1): 140-145. https://doi.org/10.1016/j.tvj1.2011.09.019

Martínez-García JA, Garcia-Lopez JC, Hernández-García PA, Mendoza-Martínez GD, Vázquez-Valladolid A, Mejia-Delgadillo MA, Lee-Rangel HA (2021). Changes in Productive Performance, Blood Metabolites and Hematological Parameters of Growing Lambs Supplemented with Two Sources of Choline. Indian J. Anim. Res. 1: 6.

Mejia-Delgadillo MA, Lee-Rangel HA, Hernandez-Garcia PA, Vazquez-Valladolid A, Mendez-Cortes H, Guerra-Liera JE, Lopez-Insunza HJ (2021). Effect of a polyherbal additive on performance and parasite infection of hair creole ewes.
Indian J. Anim. Res., 1, 5. 10.18805/IJAR.B-1370. https:// doi.org/10.18805/IJAR.B-1370

Mendoza GD, Oviedo MF, Pinos JM, Lee-Rangel HA, Vázquez A, Flores R, Cifuentes O (2020). Milk production in dairy cows supplemented with herbal choline and methionine. Rev. Fac. Cienc. Agrar., Univ. Nac., 52(1): 332-343. https://revistas.uncu.edu.ar/ojs/index.php/RFCA/article/ view/3076

NRC (2001). Nutrient Requirements of Dairy Cattle. National Research Council, The National Academies Press, Washington, DC, USA.

Ortega-Alvarez NI, Mendoza Martínez G, Ricardo Barcena Gama, Pedro Abel Hernández García, Enrique Espinosa Ayala, José Antonio Martínez García, Adrian Gloria Trujillo (2020). Economic impact of polyherbal mixtures containing choline, lysine and methionine on milk production and health of dairy cows. Emirates J. Food Agric. 864-870. https://doi: 10.9755/ejfa.2020.v32.i12.2219.

Osorio JS, Trevisi E, Ji P, Drackley JK, Luchini D, Bertoni G, Loor JJ (2014). Biomarkers of inflammation, metabolism, and oxidative stress in blood, liver, and milk reveal a better immunometabolic status in peripartal cows supplemented with Smartamine M or Meta Smart. (2014). J. Dairy Sci., 97: 7437-7450. https://doi.org/10.3168/jds.2013-7679

Patton RA (2015). Effect of rumen-protected methionine on feed intake, milk production, true milk protein concentration, and true milk protein yield, and the factors that influence these effects: A meta-analysis. J. Dairy Sci. 93: 2105-2118.

Pinotti L, Campagnoli A, Dell'Orto V, Baldi A (2005). Choline: Is there a need in the lactating dairy cow? Livest. Prod. Sci., 98(1-2): 149-152. https://doi.org/10.1016/j. livprodsci.2005.10.013

Rahmani M, Dehghan-banadaky M, Kamalyan R (2014). Comparison between feeding rumen-protected choline and vitamin $\mathrm{E}$ on milk yield and blood metabolites in early lactation dairy cows. Anim. Prod. Sci., 55(6): 752-757. https://doi.org/10.1071/AN14429

Rajala-Schultz Pj, Saville WJA, Frazer GS, Wittum TE (2001). Association between milk urea nitrogen and fertility in Ohio dairy cows. J. Dairy Sci., 84(2): 482- 489. https://doi. org/10.3168/jds.S0022-0302(01)74498-0

Roque-Jiménez JA, Mendoza-Martínez GD, Vázquez-Valladolid A, Guerrero-González MdlL, Flores-Ramírez R, PinosRodriguez JM, Loor JJ, Relling AE, Lee-Rangel HA (2020). Supplemental herbal choline increases 5-hmC DNA on whole blood from pregnant ewes and offspring. Animals, 10(8): 1277. https://doi.org/10.3390/ani10081277

Sales J, Homolka P, Koukolova V (2010). Effect of dietary rumen-protected choline on milk production of dairy cows: A meta-analysis. Int. J. Dairy Sci., 93(8): 3746-3754. https:// doi.org/10.3168/jds.2010-3106

Sánchez N, Lee-Rangel HA, Martínez-Cortés I, Mendoza GD, Hernández PA, Espinoza E, Vazque Valladolid A, Flores Ramírez R, Roque-Jimenez A, Campillo-Navarro M, Relling AE (2021). A polyherbal phytogenic additive improved growth performance, health, and immune response in dairy calves. Food Agric. Immunol., 32(1): 482-498. https://doi.or $\mathrm{g} / 10.1080 / 09540105.2021 .1967296$

Zhou Z, Bulgari O, Vailati-Riboni M, Trevisi E, Ballou MA, Cardoso FC, Luchini DN, Loor JJ (2016). Rumen-protected methionine compared with rumen-protected choline improves immunometabolic status in dairy cows during the peripartal period. Int. J. Dairy Sci., 99: 8956-8969. https:// doi.org/10.3168/jds.2016-10986 